\title{
Comparative flower peduncle anatomy of three hydrophytes from the Danube Delta
}

\author{
BERCU RODICA
}

\begin{abstract}
BERCU R. 2005. Comparative flower peduncle anatomy of three hydrophytes from the Danube Delta. Chorn. Botan. Journ., vol. 1, № 1: 47-52.
\end{abstract}

The article comprises comparative investigation of the flower peduncle in three floating hydrophytes from the Danube Delta. The anatomical features of the peduncle structure of Nymphaea alba L., Nuphar luteum (L.) Sibth. \& Sm. and Hydrocharis morsus-ranae L. are in accordance with their floating nature. Each peduncle tissue has been described and discussed, illustrations included.

Keywords: Nymphaea alba, Nuphar luteum, Hydrocharis morsus-ranae, hydrophytes, Danube Delta

Ключові слова: Nymphaea alba, Nuphar luteum, Hydrocharis morsus-ranae, гідрофіти, дельта Дунаю

\section{Introduction}

Nymphaea alba L., Nuphar luteum (L.) Sibth. \& Sm. (fam. Nymphaeaceae) and Hydrocharis morsus-ranae L. (fam Hydrocharitaceae), are rooted floating hydrophytes, living in large aquatic areas from the Danube Delta. Water lily (Nymphaea alba) flower is showy white and aromatic. The spatterdock (Nuphar lutea) flowers are yellow and "halfopened" at or above the water surface. Flowers are attached to thick round peduncles that are often six feet long. European frog-bit (Hydrocharis morsus-ranae) is an aquatic species with thick rounded floating leaves and flowers about one inch in diameter with three white petals, each with a yellow blotch. In Romania it is known as small "nuphar" [ANDERBERG, 2001; CAtling, \& Dore, 1982; SÃVulescu, 1958; Strasburger, 1991]. Some authors noticed, sporadically, the peduncle anatomy of Nymphaea alba, mostly the aerenchyma and trichosclereids [TARNAVSCHI, 1974; SALYSBURY \& ROSS, 1991; BAVARU \& BERCU, 2002; BATANOUNY, 1992], other authors described the aerenchyma tissue of the leaf petiole of Nuphar lutea [Bouman \& Houthuesen, 1996, VAN Tieghen in TARnAVSCHI \& AL., 1974]. The knowledge on the peduncle anatomy of Hydrocharis morsus-ranae is almost lacking.

\section{Material and Methods}

The vegetal material was collected from the Danube Delta channels. Small pieces of peduncle were fixed in formalin aceto-alcohol, clarified with chloral hydrate and stained with carmine alum and iodine-green. The microphotographs and observations were performed with a BIOROM-T bright field microscope, equipped with a TOPICA-1006A video camera, using scanning technique.

\footnotetext{
(C) R. Bercu

Чорн. Ботан. Журн., 2005, T. 1, № 1: 47-52.
} 


\section{Results and Discussion}

Cross sections of the flower peduncle of Nymphaea alba, Nuphar luteum and Hydrocharis morsus-ranae revealed almost the same structure that is an epidermis, a hypodermis, an aerenchyma and the vascular bundles.

The outermost layer of thin-walled barrel shaped cells is epidermis, covered by a thin cuticle. Epidermal cells are characterized by the presence of chloroplasts. The epidermal cells bear characteristic trichomes. However the epidermal multicellular trichomes of Nymphaea alba are simple while those of Nuphar luteum are unicellular and simple, lacking in Hydrocharis morsus-ranae peduncle (Fig. 1A, B)
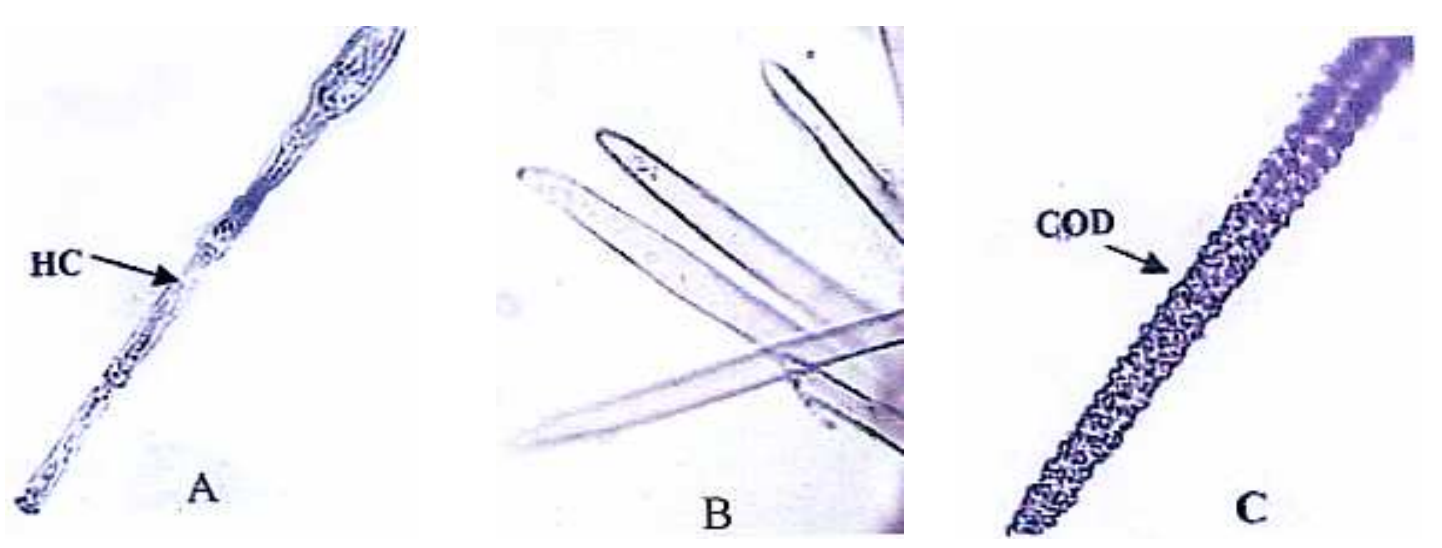

Fig. 1. Trichomes from the peduncle of: A - Nymphaea alba L. (x 176); B - Nuphar luteum (L.) Sibth. \& Sm. (x 235); C - trichosclereids form the cortex of Nymphaeae alba L. (x 250): COD - calcium oxalate deposes; HC - hair cell. Orig.

The cortex is differentiated into two zones. Externally the cortex is a collenchyma tissue, consisting of 6-7 layers in Nuphar luteum and Nymphaea alba, compactly arranged without intercellular spaces (Figs. 2A; 3B), missing in Hydrocharis morsus-ranae. The inner one is an aerenchyma. Note the presence of the unbranched trichosclereids only in Nymphaea alba cortex, deposing calcium oxalate crystals (Fig. 5A).

Bellow the collenchyma tissue (Nuphar luteum and Nymphaea alba), respectively, epidermis (Hydrocharis morsus-ranae) is the continuous mass of ground tissue (aerenchyma), characterized by large air spaces (air chambers), are separated from one another in particularly (Fig. 5B). The air chambers of Nuphar luteum are separated by thin-walled uniseriate partitions such as in Hydrocharis morsus-ranae. Those of Nymphaea alba are separated by multiseriate partitions (Figs. 2B; 3B). In the ground tissue of Hydrocharis morsus ranae peduncle, numerous large taniniferous cells are present (Fig. 5D).

A characteristic feature of the ground tissue in Nynphaea alba and Nuphar luteum is the presence of trichosclereids (asterosclereids) which are of various shapes, branched (starshaped sclereids) and unbranched. They protrude inside the air chambers. They differ from one another. However, the astrosclereids in Nuphar luteum are short and thick branched, while those of Nymphaea alba are long, thin branched, lacking in Hydrocharis morsus-ranae peduncle. All sclereids contain depositions of calcium oxalate crystals (Figs. 2B; 3B). 

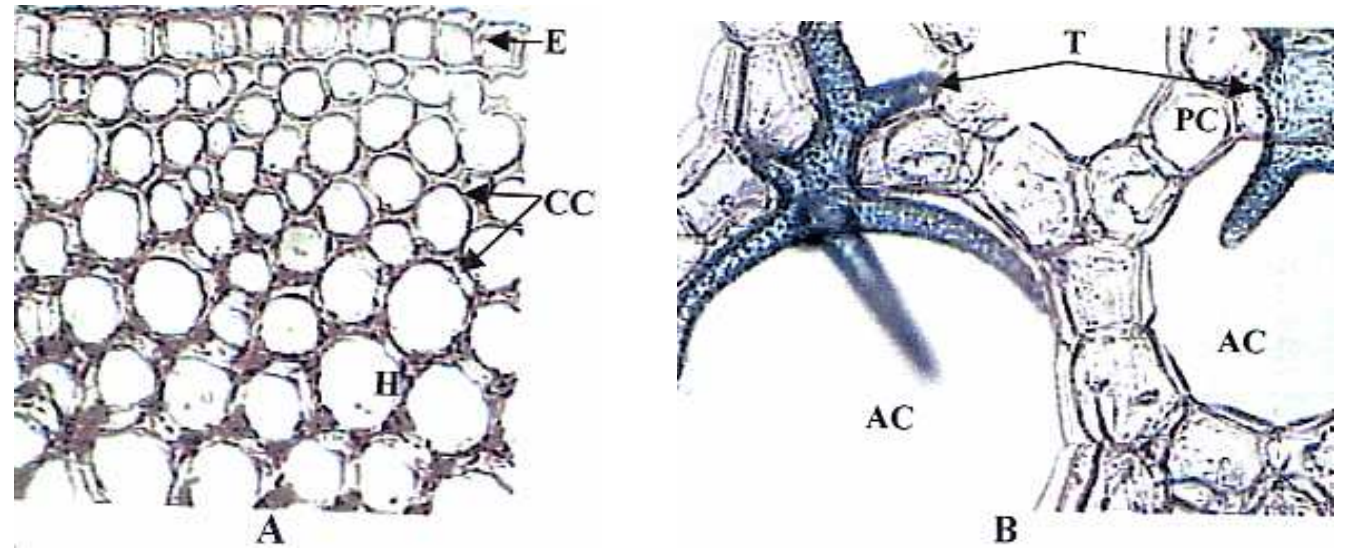

Fig. 2. Cross section of peduncle of Nuphar lutea (L.) Sibth. \& Sm. Cortex (A); Aerenchyma (B). X 280: AC- air chambers; CC- collenchyma cells; E- epidermis; PCparenchyma cells; $\mathrm{T}$ - trichosclereids. Orig.
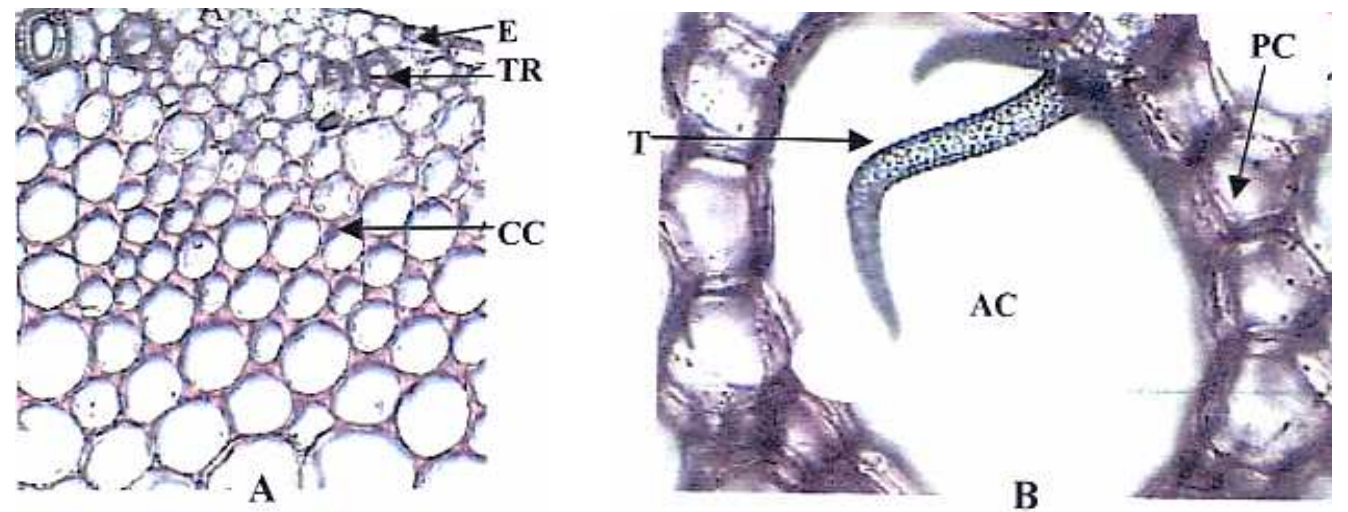

Fig. 3. Cross section of peduncle of Nymphaea alba $\mathrm{L}$. Portion with epidermis and cortex (collenchyma). X 125. Aerenchyma (B). X 245: AC- air chambers; CC- collenchyma cells; E- epidermis; PC- parenchyma cell; T- trichosclereids; TR- trichosclereid roots. Orig. 
The vascular system of Nymphaea alba and Nuphar luteum peduncle is represented by a number of vascular bundles irregularly embedded in the ground tissue. Between the air chambers, the vascular bundles are surrounded by parenchyma cells. The vascular tissue is poorly developed, xylem being represented by a single large lacuna. Phloem shows a normal development. However two types of vascular bundles may be found: smaller vascular bundles with only one group of phloem on either side of xylem, commonly found towards central region and larger vascular bundles, with usually two or three groups of phloem on either side of xylem lacuna, commonly found towards the central region (Fig. 4 A-C). Small taniniferous cells and starch grains are present in between the parenchyma cells (Fig. 4B).
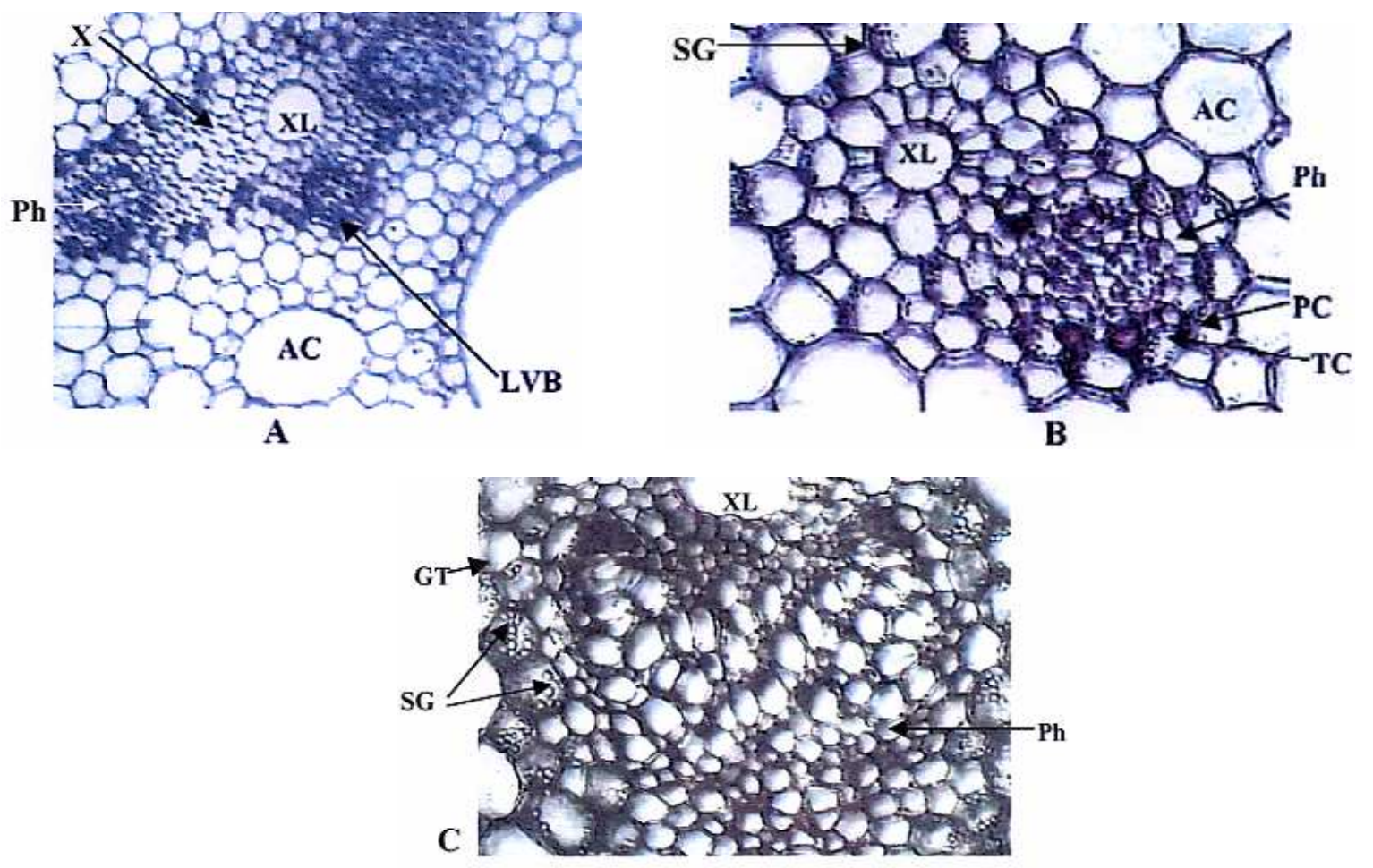

Fig. 4. Cross section of the peduncle. General view of the vascular bundle of Nymphaea alba L. (A). X 71. Detail of a vascular bundle of Nymphaeae alba L. (B).-X 181. A vascular bundle of Nuphar luteum (L.) Sibth. \& Sm. stele (C). X 198: AC- air chamber; GT- ground tissue; LVB- large vascular bundle; Ph- phloem; PC- parenchyma cells; SG- starch grains; TC- taniniferous cell; X- xylem; XL- xylem lacuna. Orig.

The vascular system of Hydrocharis morsus-ranae peduncle is represented by a large centrally located collateral vascular bundle (Fig. 5C) and small vascular bundles below the epidermis (Fig. 5A). The central vascular bundle is surrounded by a parenchymatous sheath (Fig. 5C). 

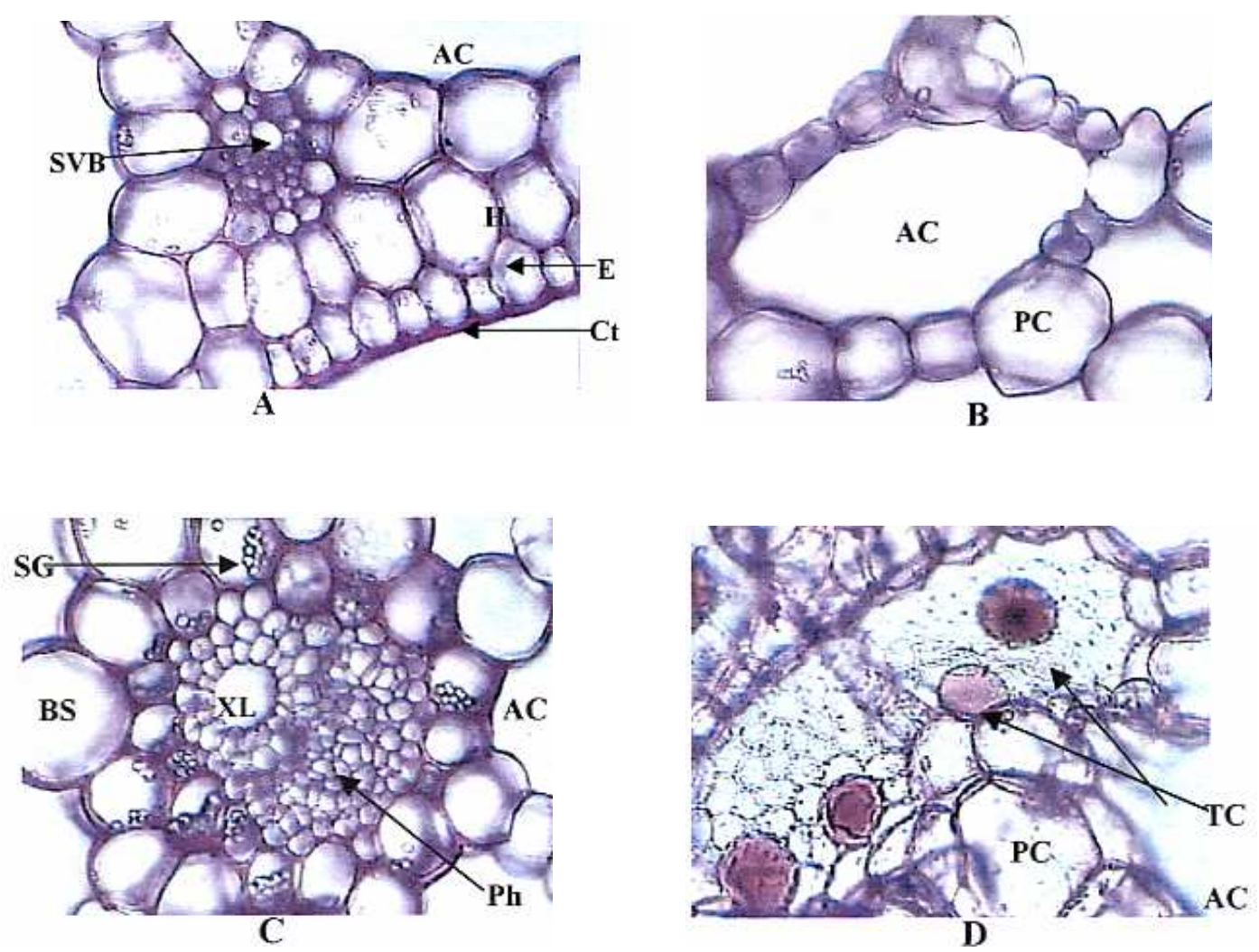

Fig. 5. Cross section of the peduncle of Hydrocharis morsus-ranae. L. Portion with epidermis and cortex (A). Aerenchyma (B). Central vascular bundle (C). Air chamber with taniniferous cells (D). X 240: AC- air chamber; Ch- chloroplasts; Ct- cuticle; BSbundle sheath; E- epidermis; GT- ground tissue; H- hypodermis; LVB- large vascular bundle; Ph- phloem; PC- parenchyma cells; SG- starch grains; SVB- small vascular bundle; TC- taniniferous cells; XL- xylem lacuna. Orig.

\section{Conclusion}

Results reveal that the flower peduncles of Nuphar luteum, Nymphaea alba and Hydrocharis morsus-ranae are differed by some anatomical characteristics such as the type of trichomes, the features of the trichomes, the astrosclereids configuration and the number of parenchyma cells which separate the air chambers of the ground tissue. In the ground tissue of Hydrocharis morsus-ranae peduncle taniniferous cells occur and starch grains. The vascular system is represented by a number of closed collateral vascular bundles in Nymphaeaceae species and by a single one in Hydrocharis morsus-ranae. Phloem is prominent and located in the outer part of the bundle, whereas xylem consists often of a single large lacuna.

\section{References}

ANDETBerg, A., A. Den Virtuella floran-world mide wels, Electronic publication, 2001.

BAtanouny K. H. Plant Anatomy. A Textbook of Botany. - Cairo: University Press, 1992. - 627 p. BAVARU A., BERCU R. Morfologia şi anatomia plantelor. - Constanța: Ex Ponto, 2002. - 389 p.

Bouman F., Houtuesen J. Strukturele botanie. 2. Weefsels, CD-ROM Versie, SEP, Hugo de Vries laboratorium. -1996. 
CAtLING P.M., DORE W.G. Status and identification of Hydrocharis morsus-ranae and Limnobium spongia (Hydrocharitaceae) in northeastern North America // Rhodora. - 1982. - № 84 (840). P. 523-545.

Furnari G., Guglielmo A., LONGHitano N., SAlmeri C., SCElsi F. Tavoli di anatomia dei vegetali vasculari. - Edit. by Pavone P. - Catalania University Press, 1998. - 20 p.

SAlisbury F. B., Ross C. W. Plant physiology ( $4^{\text {th }}$ ed. $)$ - Belmond: Wadsworth Publishing Company, 1992. $-134 \mathrm{p}$.

SÃVUlESCU T. (Editor-in Chief). Flora României. București: Editura. Academiei Române, 1955. Vol. VI. $-676 \mathrm{p}$.

STRASBURGER E. Lehrbuch der Botanik für Hochschulen. 33 Auflage. - Stuttgart, Jena, New York, Gustav Fischer Verlag, 1991. - 1030 p.

TARNAVSCHI T. I., ŞERBÃNESCU-JITARIU G., RÃDUlESCU-MitroIU N., RÃDUlESCU D. Practicum de morfologia şi anatomia plantelor. - Bucureşti: Tipografia Universitãţii, 1974. - 411 p.

Рекомендує до друку

Отримано 02.03.2005 p.

А.В. Сна

Author's address:

Bercu Rodica

"Ovidius" Univerity

Faculty of Natural Science

Department of Vegetal Biology

Mamaia Str. 124,

8700 Constanza, Romania

E-mail: rodicabercu@yahoo.com
Adpeca автора:

Берку Родіка

Університет ім. Овідія,

Природничий факультет,

Кафедра біології рослин,

Вул.Мамайя, 124,

Констанияа, 8700

Румунія

E-mail: rodicabercu@yahoo.com 